УДК: 338.28

JEL Classification: E22, F21, O16, O31, O33

DOI 10.35433/ISSN2410-3748-2020-2(27)-7

\author{
Iryna Mosiichuk \\ PhD, Senior Lecturer \\ Department of Economics, \\ ORCID 0000-0001-7664-7853
}

management, marketing and hotel and restaurant business

Ivan Franko Zhytomyr State University

Iryna Poita

PhD, Senior Lecturer

Department of Economics,

management, marketing and hotel and restaurant business

Ivan Franko Zhytomyr State University

ORCID 0000-0003-2137-3706

Ukraine

\title{
ECONOMY DIGITALIZATION AS A DIGITAL TRANSFORMATION TOOL OF UKRAINE
}

The article explores digital technologies as one of the significant components of our daily life. The concept of "digital economy" is seen not only as a trade via the Internet, but also as a factor of increasing the investment climate, as a new quality of the economy or a separate sector of the economy, and is the result of the fourth stage of globalization-digital transformation. Which consists in fundamental change of the structure of world economy

based on its global virtualization. It is determined that digitalization is a radical transformation, which is expressed in the deep penetration of digital technologies into the economy, business processes, their optimization, increasing productivity and improving communication with consumers. It is noted that with the extand of the degree of environment variability the role of digitalization as a global phenomenon accelerates significantly, which becomes one of the leading factors in the development of the world economy, as far as the competitiveness of some countries is determined by implementation level of innovative technologies. The indicators of global indices of digital economy development for Ukraine are considered, the global rating of Ukraine by the level of innovations is determined.

It is noted that an important component of the formation of the information society in 
Ukraine is the feasibility of using modern information and communication technologies (ICT). Based on the results of the analysis the author reveals index of countries included in the rating, which is calculated by 7 indicators with different weighting coefficients. A comparative analysis of data on the use of computers and computer networks and access to the Internet in Ukraine is carried out. Computer technologies are singled out as a priority direction of innovative development of production and economic systems of different levels and a tool of competitive advantages over the longer term.

Key words: digitalization, digital economy, digital technologies, digitization, digital transformation

\section{ДІДЖИТАЛІЗАЦІЯ ЕКОНОМІКИ ЯК ІНСТРУМЕНТ ЦИФРОВОЇ ТРАНСФОРМАЦІЇ УКРАЇНИ}

В статті досліджено цифррові технології як одна із значних складових нашого повсякденного життя. Поняття «цифрова економіка» розглядається не лише як торгівля за допомогою мережі Інтернет, а й як чинник збільшення інвестииійного клімату, як нова якість економіки або окремий сектор економіки, є результатом четвертого етапу глобалізації - цифрової трансформащії, щзо полягає в принциповій зміні структури світової економіки на основі ї̈ глобальної віртуалізації. Визначено, щуо діджиталізація являє собою корінні перетворення, щуо находять вираження в

глибокому проникненні ичирових технологій в економіку, у бізнес-процеси, їх оптимізащії, підвищенні продуктивності та поліпшенні комунікаційної взаємодії зі споживачами. Зазначено, що у міру прискорення ступеня мінливості зовнішнього середовища значно зростає роль діджиталізаціі як глобального явища, щзо стає одним із провідних факторів розвитку світової економіки, оскільки конкурентоспроможність окремих країн обумовлена рівнем реалізаиії інноваційних технологій. Розглянуто показники глобальних індексів розвитку цифрової економіки для України, визначено глобальний рейтинг Украйни за рівнем інновачій. Зазначено, щуо важливою складовою формування інформаційного суспільства в Україні є використання можливостей сучасних інформачійно-комунікаційних технологій (IКT). За результатами аналізу

авторами розкрито індекс краӥн, щз входять у рейтинг, щзо розраховується на підставі 7 індикаторів з різними ваговими коефіцієнтами. Проведено порівняльний аналіз даних щуодо використання комп 'ютерів $і$ комп'ютерних мереж та доступу до

використання Інтернету в Україні. Виокремлено комп ютерні технології як першочерговий напрям інноваційного розвитку виробничо-економічних систем різних рівнів та інструмент забезпечення конкурентних переваг у довгостроковій перспективі

Ключові слова: діджиталізація, цифрова економіка, циифрові технології, ичифровізачія, иифрова трансформачія

Problem statement. The formation of the digital economy in Ukraine should become a driving force for increasing GDP and improving living standards. Using digital technologies, each sector of the economy can grow faster, better and more efficiently. This leads to a wide interest of scientists in the concept of digital economy and digitalization. 
Digitalization is a radical transformation, which is expressed in the deep penetration of digital technologies into the economy, business processes, their optimization, increasing productivity and improving communication with consumers. The key feature of such transformations is significant improvements in the efficiency of economic and business processes, reduction of money and time spent on their support.

Though it is paid much attention to the study of various aspects of the digital economy in scientific literature, the digital transformation contains a number of key aspects that remain insufficiently disclosed: in particular, its development in Ukraine, the integrated implementation of digital technologies in the economic system and at enterprises, change of the requirements for functional responsibilities and defining the content of digital skills and competencies of employees.

Analysis of recent research and publications. A lot of works both by domestic and foreign authors are devoted to the study of various aspects of the transformation and development of the digital economy. In particular, Dannikov O. V. and Sichkarenko K. O. directed their research to the identifying the conceptual foundations of digitalization of economy in Ukraine [4]. Chesnokova N. V. analyzed the development of the digital economy and society in the EU - states and in Ukraine and highlighted its most significant problems for our country [9]. Manzhosov A. E. identified structural shifts in the digital economy and digitalization of services markets, consumer loyalty in the international capital market [5]. Starodubtseva E. B., Markova O. M. investigated the reasons of the current state of digitalization of the domestic and world economy on the basis of indices and provided some recommendations for improving the situation [7]. Guseva O. Y., Gudz O. Y covered the issue of digitalization, economy modernization of Ukraine due to the development of its digital component, investigated trends of digital platforms development [2;3]. 
Purpose of the article is research of problems and key aspects of digitalization of the economy as a tool of digital transformation of Ukraine on the basis of international ratings and indicators of digital technologies, innovations, identification of problems that inhibit the development of digitization.

Presenting main material. The digital economy is the result of the fourth stage of globalization - digital transformation, which consists in a fundamental change in the structure of the world economy on the basis of its global virtualization. To meet the latest conditions of the business environment, companies choose the path of digital development. Practice shows that such a choice can help them to ensure high rates of economic development and efficiency in the long run, increase competitiveness at national and global markets.

The digital economy is a market type of subjects of economic system at which one, several or all stages of economic processes are carried out via computer networks; one of the manifestations of economic freedom, innovativeness and the level of economic development [2].

The processes of digitization and digital transformation are the driving forces stimulating change in the corporate world, based on the implementation of new technologies such as big data analysis, the Internet of things, cloud technologies or $3 \mathrm{D}$ printing. Analog information is being converted to digital data. The constant convergence of the physical and digital worlds encourages companies to integrate, for example, the Internet things and services into production processes, create value through analysis and management of big data, which can be used as a competitive advantage [4].

Most of the changes caused by digitalization are destructive and radically change existing industries; companies that occupy a dominant position at the market, face new competitors, and existing business models go out of date and are replaced by new ones. 
At the international level, integrated assessment of the state of development of the innovation system is widely used. Ukraine is represented in several international ratings that assess innovation potential, technological and innovative competitiveness. The most authoritative are the Global Innovation Index Global Innovation Index, Bloomberg Innovation Index, Global Competitiveness Index, Innovation Union Scoreboard, Global Talent Competitiveness Index, Readiness for the Future of Production Assessment [6].

Indicators of global indices of digital economy development for Ukraine were estimated by world organizations for the period from 2016 to 2018 (Fig. 1).

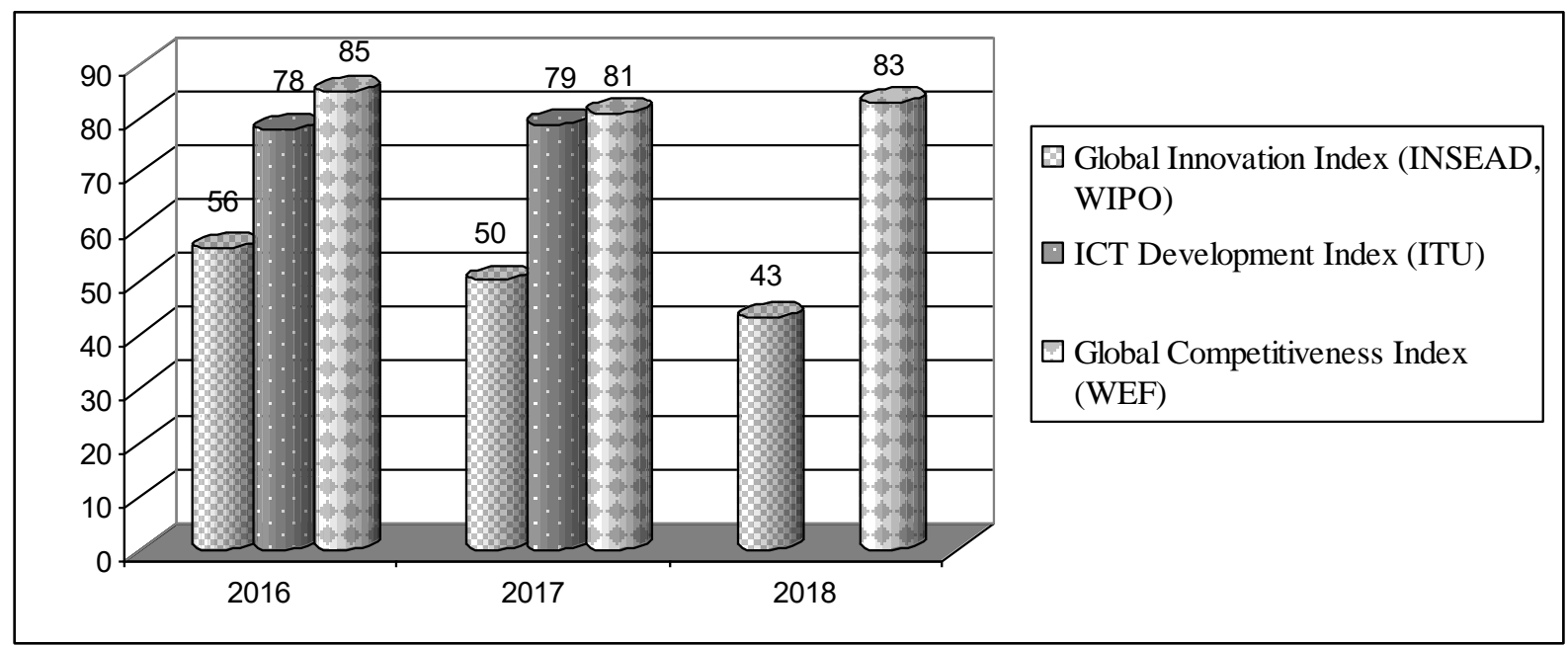

Source: generated by the authors based on [6]

Fig. 1. Indicators of global indices of digital economy development for Ukraine

Global Innovation Index (INSEAD, WIPO) - innovation index, which is published with the support of the World Intellectual Property Organization. According to this rating, Ukraine has rapidly improved its position for two years and tends to obtain the expected result in 2020 [6].

ICT Development Index (ITU) - index, which characterizes the achievements of countries in the development of information and communication technologies, calculated and published by a special UN unit [6]. 
The Global Competitiveness Index - global study and the accompanying rating of countries in the world in terms of economic competitiveness. Calculated according to the methodology of the World Economic Forum (WEF), based on a combination of publicly available statistics and the results of a global survey of company executives - a large annual survey conducted by WEF together with a network of partner organizations - leading research institutes and organizations in the countries analyzed in the report [6] .

The digital economy is based on the usage of digital computer technologies. It is defined as a priority area of innovative development of production and economic systems of different levels and a tool to ensure competitive advantage in the long run. In view of this, affirmation of a number of scholars rightly characterizes the digital economy as "an accelerator of socioeconomic life of society and a key driver of GDP growth."

According to the statistics shown in Figure 2, Ukraine has improved its position in the global rating of innovation in the last five years. Despite the downgrade in 2018 and 2019, Ukraine remains among the countries in the Lower-middle Income category that has high expectations for the level of development.

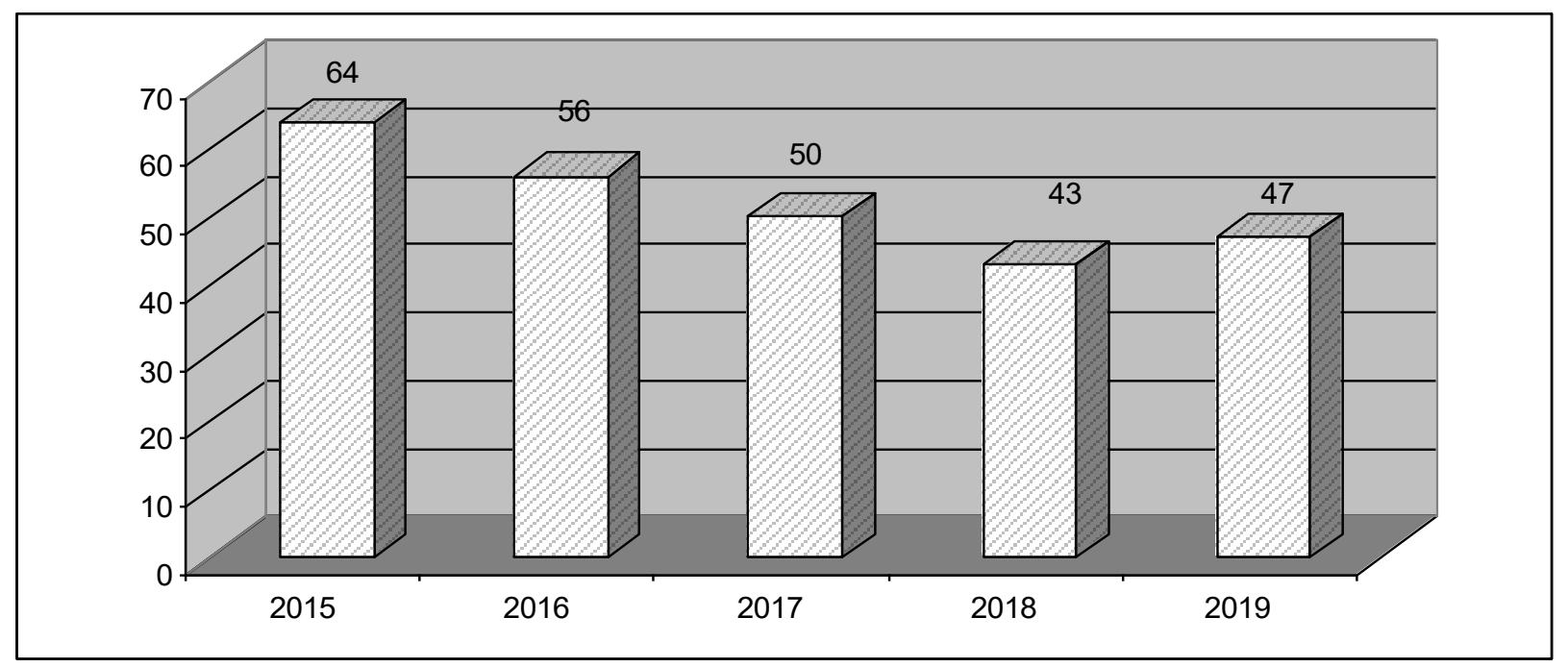

Source: generated by the authors based on [6]

Fig. 2. Ukraine's global rating by level of innovation 
In 2018, Ukraine moved up in the rating by another 7 positions and took 43rd place, being ahead of Thailand and behind Croatia and Greece. And in the group of below-average incomes, Ukraine took 1st place, beating Vietnam [6].

It is worth to mention, that this indicator characterizes the economy of Ukraine as having a high coefficient of innovation efficiency (works better than one would expect from the level of investment). At the same time, in terms of investments in innovations in 2019, our country ranks only 82nd.

According to Bloomberg South Korea once again became the leader in the rating of the most innovative countries in the world. Germany moved up in the ratring by two positions and took 2 nd place. Finland went up by four positions and took third place. Switzerland and Israel were also in the top five in 2019.

As the degree of variability of the environment accelerates, the role of digitalization as a global phenomenon increases significantly, which becomes one of the leading factors in the development of the world economy, because the competitiveness of some countries is determined by the level of implementation of innovative technologies. At the present stage, an important task is to assess the level of innovation development in terms of individual country.

The index of countries included in the rating is calculated on the basis of 7 indicators with different weighting coefficients:

- R\&D intensity (20\%) - R\&D expenditures as a percentage of GDP;

- productivity (20\%) - the volume of GDP in terms of 1 hour of working time;

- concentration of high technologies (20\%) - the share of high-tech companies in the total number of registered firms. High-tech companies include companies engaged in the aerospace and defense industries, biotechnology, developments in the field of nano- and microelectronics, software, etc;

- concentration of researchers $(20 \%)$ - the number of researchers in the field of R\&D per 1 million population; 
- technological capabilities (10\%) - the share of technological products in total GDP (\%); the share of R\&D products in the total volume of exported technological products;

- level of high education (5\%) - the share of graduates in the field of high education working in science, technology, industry and construction; the share of university graduates in the total labor force in the country (population aged $15-64)$;

- patent activity (5\%) - the share of patents issued in the country, from the total number of applications filed and confirmed in the world.

Ukraine occupied 53rd place in the rating with a total score of 48.05. A year earlier, our country occupied $46^{\text {th }}$ place. This decline is due to the weakening of Ukraine's position by 6 of the seven components of this index (Fig. 3).

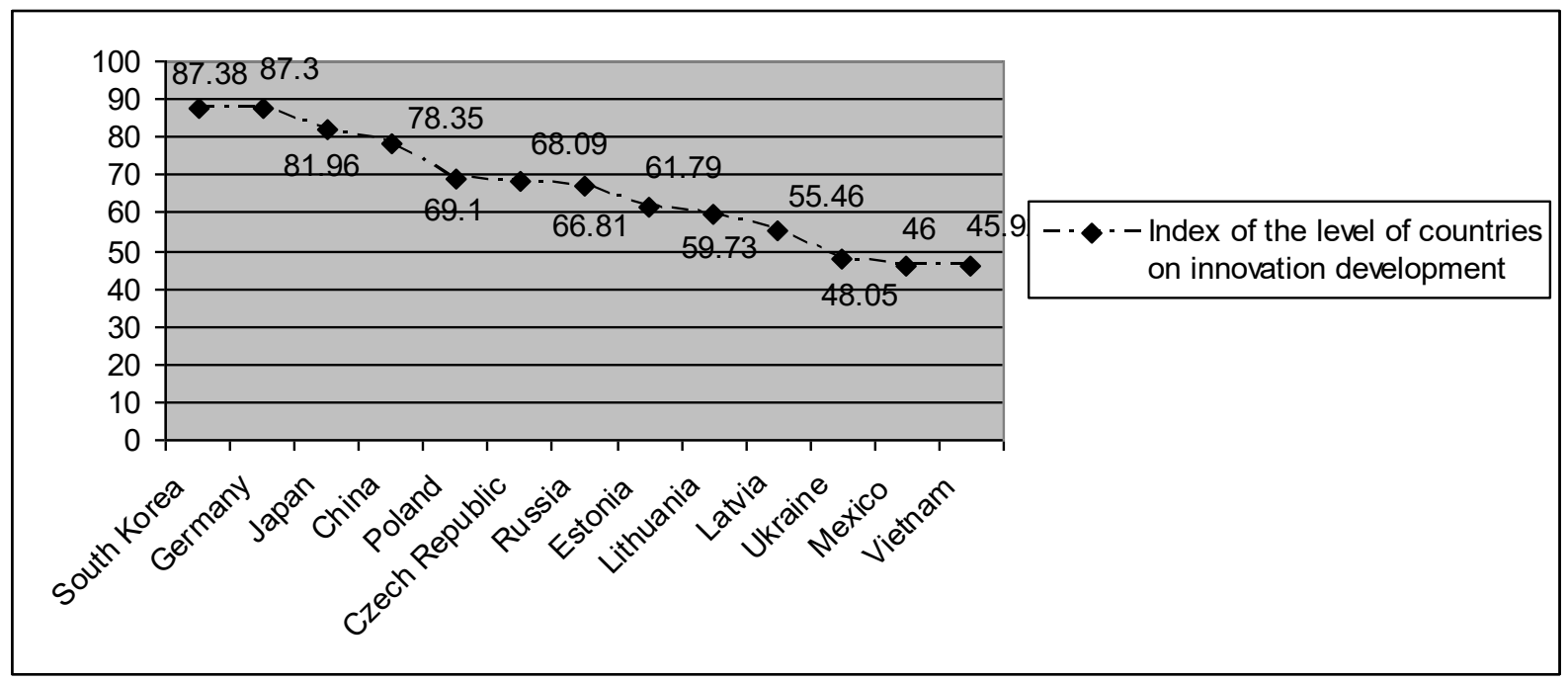

Source: generated by the authors based on [6]

Fig. 3. Index of the level of countries from innovative development, $\%$

At the same time, it should be noted that this year 10 new countries appeared in the rating, which were absent in the last year's version of the rating. At the same time, 4 of them (Slovenia, Brazil, the United Arab Emirates and 
Argentina) were ranked higher than Ukraine and actually pushed it out of TOP50.

An important component of the formation of the information society in Ukraine is the usage of modern information and communication technologies (ICT) to create information and knowledge, use and share them, produce goods and provide services, contributing to the sustainable development of the country. The use of ICT in the context of intensive development of market relations is one of the most important elements of effective management.

Information and communication technologies are unified information technologies and integration of telecommunications (telephone lines and wireless connections), computers, middleware, software, storage and audiovisual systems that allow users to create, access, store, transmit and modify information.

Global costs at the ICT market in 2018 amounted to about \$ 4.81 trillion and, according to analytical agencies, are expected to increase to $\$ 6$ trillion (Fig. 4).

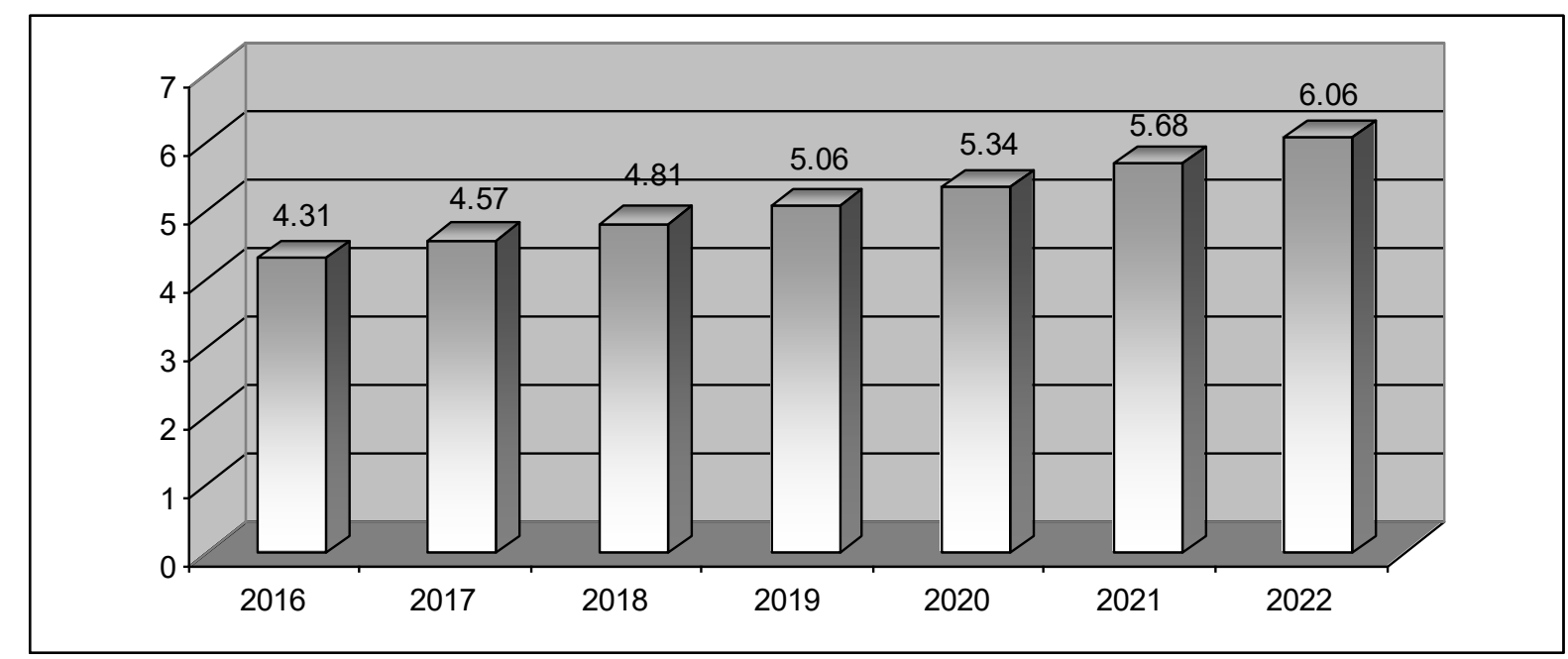

Source: generated by the authors based on [6]

Fig. 4. Global costs for ICT in 2016-2022, trillion \$. USA

If we talk about the use of ICT at the enterprises of Ukraine, according to the State Statistics Service of Ukraine in 2018, in total $95.5 \%$ of domestic 
enterprises use computers for their activities (this is $0.3 \%$ more than in 2015), and $98.1 \%$ of enterprises have access to the Internet $(0.1 \%$ more than in 2015$)$ (Fig. 5).

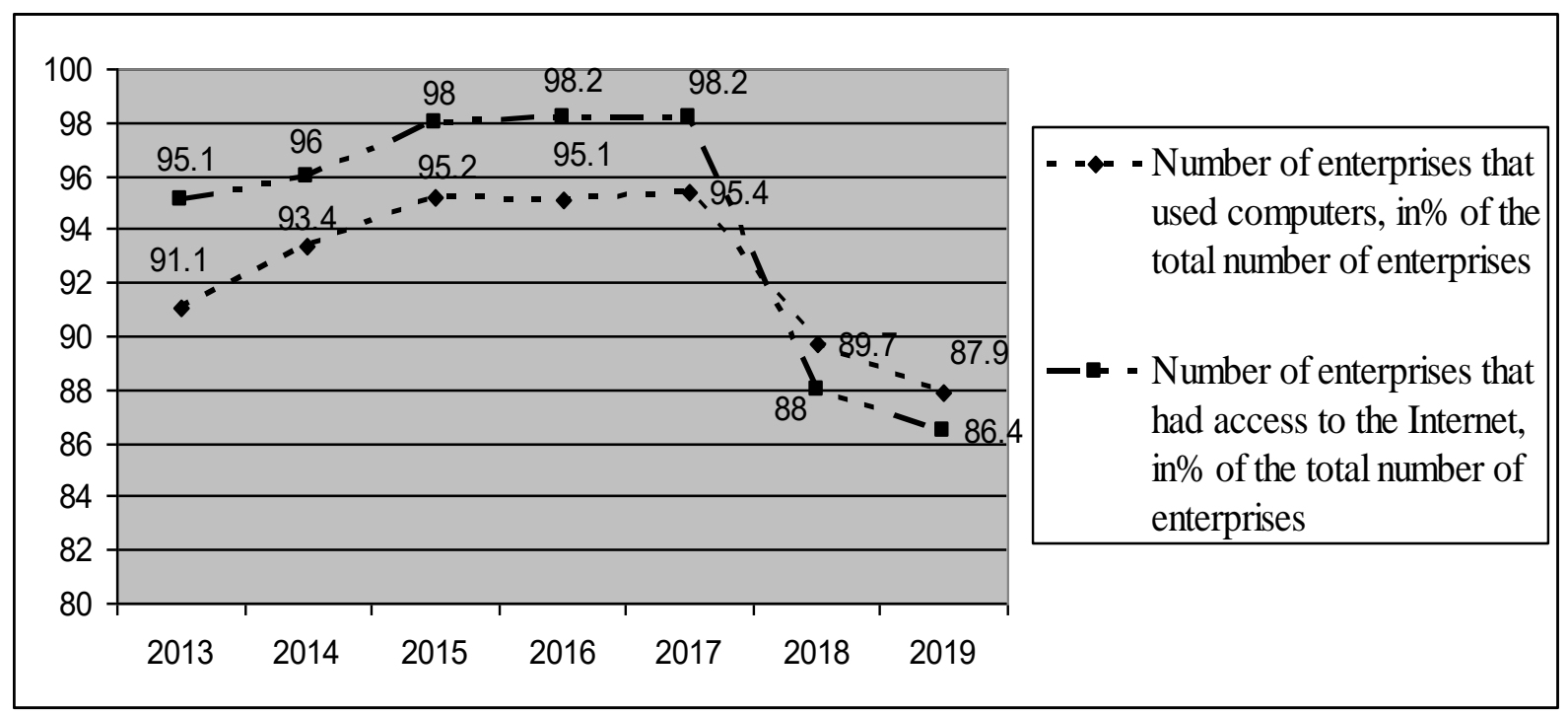

Source: generated by the authors on the basis of data from the State Statistics Service of Ukraine

Fig. 5. Usage of ICT at the enterprises of Ukraine, \%

Overall, the ICT sector is expected to more than double GDP growth over the next decade as new technologies begin to consist a large market share.

The advent of the Internet of Things (IoT) is already contributing to the overall growth of the market, and within 5-10 years new technologies such as robotics, augmented and virtual reality (AR/VR) will also expand to consist significant and growing share of total ICT costs. The largest costs will be fallen on telecommunication technologies and new technologies.

As can be seen from the Figure 6, the number of Internet users in Ukraine floates year on year. The percentage analysis shows that in the period from January 2015 to January 2016 the share of Internet users in relation to the population of the country was $43.4 \%$ in Ukraine, for the next three analyzed periods it was $49.2 \%, 58 \%$ and $93.1 \%$, respectively.

Ukraine's population fluctuation decreased by 0.82 million people over four periods, which is quite acceptable for objective results. Also according to 
research for four years in Ukraine the number of mobile users significantly exceeds the population of the country as a whole, this is due to the fact that a large part of the population of Ukraine has several mobile devices (smartphone, i-pad) [8].

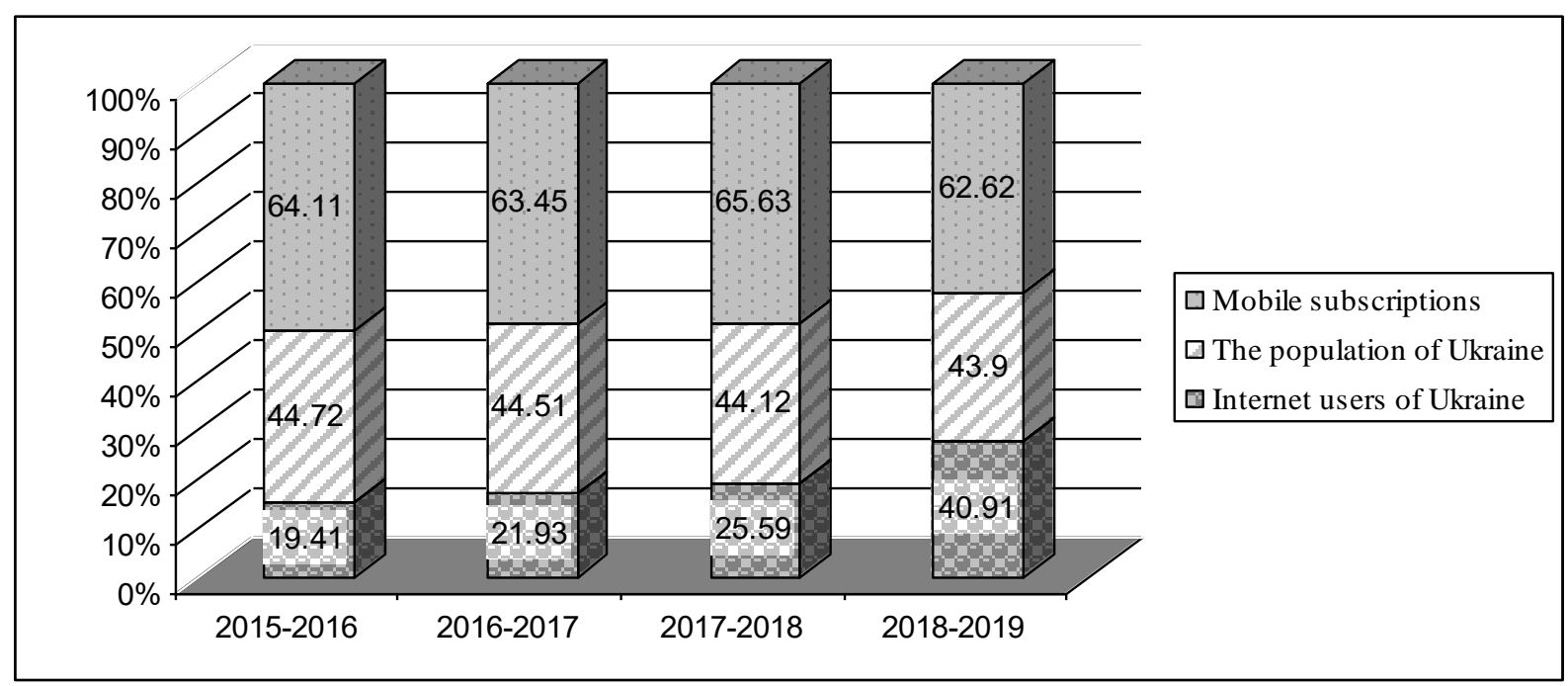

Source: generated by the authors on the basis of data from the State Statistics Service of Ukraine

Fig. 6. Dynamics of Internet use in Ukraine, \%

The expected benefit of the use of ICT in the production process and everyday life includes: increasing the efficiency of "big" data processing, optimization of production processes and their automation, transition from traditional data centers to centralized cloud analogues, increasing computing resources of modern supercomputers, new opportunities for creating "smart" home devices, connecting to a network of hard-to-reach areas, increasing the capacity of data storage devices and reducing the cost of data storage.

In Ukraine, ICT technologies for artificial intelligence and the Internet of Things are included in the list of medium-term priorities at the national level, but were not funded in 2017-2018, so the active introduction of digital technologies in economic activities is an important factor of improving its efficiency. 
Conclusions and prospects for further research. Digitalization creates important benefits for the economy as a whole and for enterprises in particular, in terms of implementing the chosen strategy, strengthening their economic security, achieving transparency in doing business. Such trends are relevant for enterprises of all sectors of economy and require state support.

In Ukraine favorable conditions for the development of digital economic infrastructure are created, but there are a number of technical features that prevent the availability of means of communication for the entire population of the country and anywhere. To do this, the state economic policy should be aimed at stimulating productivity through innovation. World practice shows that technological innovations are directly connected with positive economic indicators.

\section{REFERENCES}

1. Arenkov, I. A., Smirnov, S. A., Sharafutdinov, D. R., \& Yaburova, D. V. (2018). Transformatsiia sistemy upravleniia predpriiatiiem pri perekhode $\mathrm{k}$ tsifrovoi ekonomikie [Transformation of an enterprise management system in the transition to a digital economy]. Rossiyskoie predprinimatielstvo [Russian Journal of Entrepreneurship], vol. 5, 1711-1722 [in Russian].

2. Hudz, O. Ye. (2018). Tsyfrova ekonomika: zmina tsinnostei ta oriientyriv upravlinnia pidpryiemstvamy [Digital economy: changing values and guidelines of enterprise management]. Ekonomika. Menedzhment. Biznes. [Economy. Management. Business], vol. 2, 4-12 [in Ukrainian].

3. Husieva, O. Yu., \& Lehominova, S. V. (2018). Didzhytalizatsiia - yak instrument udoskonalennia biznes-protsesiv, yikh optymizatsiia [Digitalization - as a tool for improving business processes, their optimization]. Ekonomika. Menedzhment. Biznes. [Economy. Management. Business], vol. 1, 33-39 [in Ukrainian]. 
4. Dannikov, O. V., \& Sichkarenko, K. O. (2018). Kontseptualni zasady tsyfrovizatsii ekonomiky Ukrainy [Conceptual bases of digitalization of economy of Ukraine]. Ekonomika ta upravlinnia natsionalnym hospodarstvom [Economics and management of the national economy], vol. 17, 73-79 [in Ukrainian].

5. Manzhosov, A. E. (2018). Didzhytalizatsyia rynkov usluh i potrebitelskaia loialnost [Digitalization of service markets and consumer loyalty]. Yzvestiia Sankt-Peterburskogo gosudarstvennogo eknomicheskogo universiteta [Bulletin of the St. Petersburg State University of Economics], vol. 3 (111), 151-156 [in Russian].

6. Pysarenko, T. V. \& Kvasha, T. K. (2019). Stan innovatsiinoi diyalnosti ta diyalnosti u sferi transferu tekhnolohiy v Ukrayini u 2018 rotsi: analitychna dovidka [State of Innovation and Technology Transfer Activity in Ukraine in 2018: Analytical Reference]. Kyiv : UkrINTEI [Ukrainian Institute of Scientific and Technical Expertise and Information] [inUkraine].

7. Starodubtseva, E. B., \& Markova, O. M. (2018). Tsifrovaia transformatsiia mirovoi ekonomiki [Digital transformation of the world economy]. Vestnik AHTU. Seryia: Ekonomika [Bulletin of the Astrakhan State Technical University Series: Economics], vol. 2, 7-15 [in Russian].

8. Sait Derzhavnoi sluzhby statystyky Ukrainy [Sait of State Statistics Service of Ukraine]. http://www.ukrstat.gov.ua/. Retrieved from: http://ukrstat.gov.ua/ (Accessed 18 Oct 2020) [in Ukrainian].

9. Chesnokova, N. V. (2019). Stan ta problemy rozvytku tsyfrovoi ekonomiky ta suspilstva v YeS ta Ukraini [Status and problems of development of digital economy and society in the EU and Ukraine]. Visnyk Khmelnytskoho natsionalnoho universytetu. Ekonomichni nauky [Bulletin of Khmelnytsky National University. Economic sciences], vol. 1, $209-213$ [in Ukrainian].

Стаття надійшла до редакиії 31.10.2020 